\title{
Nucleic Acid Relationships among the Anaerobic Mycoplasmas
}

\author{
By E. B. STEPHENS, ${ }^{1}$ I. M. ROBINSON ${ }^{2}$ AND M. F. BARILE ${ }^{3 *}$ \\ ${ }^{1}$ Department of Microbiology, Oregon State University, Corvallis, Oregon 97221, USA \\ 2 National Animal Disease Center, Agricultural Research Service, US Department of Agriculture, \\ Ames, Iowa 50010, USA \\ ${ }^{3}$ Mycoplasma Branch, Center for Drugs and Biologics, Food and Drug Administration, Bethesda, \\ Maryland 20205, USA
}

(Received 14 August 1984)

\begin{abstract}
The genetic relatedness between twelve selected strains among four distinct serovars of anaerobic mycoplasmas was studied using $\left[{ }^{3} \mathrm{H}\right]$ DNA-DNA hybridization, and the results were compared with data obtained from biochemical and serological tests. Radiolabelled DNA probes were prepared from five strains representing four serovars. Based on the homology results, the anaerobic mycoplasmas can be divided into five distinct groups representing five distinct species and two distinct genera. There are two species in the Anaeroplasma bactoclasticum serovar 1 group represented by strains JR and A-2, one species in serovar 2, one species in $A$. abactoclasticum serovar 3 and one among the unclassified serovar 4 anaerobic mycoplasmas. The probe to nonsterol-requiring strain 161 of serovar 4 showed no homology with any of the established nonsterol-requiring Acholeplasma species DNAs, or with Mycoplasma hominis DNA, or with avian DNA which served as a negative control. There was good correlation between the phenotypic and genotypic properties of the five distinct anaerobic mycoplasma species but the results indicate that phenotypic properties are not always adequate for speciation of the anaerobic mycoplasmas.
\end{abstract}

\section{INTRODUCTION}

An absolute requirement for anaerobic growth conditions and a high sensitivity to oxygen distinguish the anaerobic mycoplasmas from all other mycoplasmas. Both sterol- and nonsterolrequiring anaerobic mycoplasma strains have been isolated from the rumens of cattle and sheep (Robinson \& Allison, 1975; Robinson et al., 1975; Robinson \& Rhoades, 1982). On the basis of antigenic properties, i.e. agglutination and gel diffusion precipitin tests, anaerobic mycoplasma strains were classified into four serovars (Robinson \& Rhoades, 1982) which agreed with group separation based upon cultural, biochemical and biophysical properties (Robinson, 1979; Robinson \& Rhoades, 1977; Robinson et al., 1975). Two species have been described and assigned to the genus Anaeroplasma. Both are sterol-dependent; A. bactoclasticum possesses bacteriolytic and proteolytic enzymes whereas $A$. abactoclasticum lacks these enzymes. The taxonomic position of a third group, which consists of nonsterol-requiring organisms, has not been determined, and this group is considered unclassified (Robinson, 1984).

Because the taxonomic classification of anaerobic mycoplasmas has been based solely on selected phenotypic properties, the degrees of relatedness among strains based on DNA homology should provide useful information. The amount of genetic relatedness among various mycoplasma strains and species has been determined using nucleotide sequence homology of the chromosomal DNA and these studies have provided very useful information for the taxonomic characterization of organisms belonging to the class Mollicutes (Aulakh et al., 1979, 1983; Bove et al., 1982; Chandler et al., 1982; Christiansen et al., 1981; Stephens et al., 1981, 1983). DNA hybridization data were especially useful for examining acholeplasmas and other mycoplasmas for which immunological information was somewhat lacking (Tully, 1979), and also confirmed 
the genomic relationships among strains and species classified on the basis of their phenotypic properties (Stephens et al., 1983). The purpose of the present study was to determine the relationship between the phenotypic and genomic properties of related strains among the anaerobic mycoplasmas, and to evaluate the usefulness of presently accepted procedures for the classification of anaerobic mycoplasmas.

\section{METHODS}

Organisms. Twelve anaerobic mycoplasma strains representative of four serovars classified on the basis of cultural, biophysical and metabolic properties were used (Robinson, 1979; Robinson \& Allison, 1975; Robinson et al., 1975). Strains were isolated from the following rumen contents: cow, strain JF (Robinson \& Hungate, 1973); steers, strains 10A and A-2; all other strains were isolated from rumen contents of sheep (Robinson \& Allison, 1975: Robinson et al., 1975). The differential characteristics of the strains used are listed in Table 1.

Cultitation techniques. Anaerobic mycoplasma strains were grown overnight at $37^{\circ} \mathrm{C}$ in clarified rumen fluid broth medium (Robinson et al., 1975) using the roll tube anaerobic culture technique (Robinson \& Allison, 1975; Robinson et al., 1975; Robinson \& Hungate, 1973). Anaerobic mycoplasmas will grow only in a prereduced medium maintained in a system which completely excludes oxygen: e.g. if resazurin in a test medium becomes oxidized, these organisms will not grow. Cells were sedimented by centrifugation at $10000 \mathrm{~g}$ for $15 \mathrm{~min}$, washed twice with $0.85 \%$ sodium chloride, buffered to $\mathrm{pH} 7.2$ with $0.02 \mathrm{M}$-sodium phosphate (PBS), resuspended in PBS and stored at $-40{ }^{\circ} \mathrm{C}$ until used.

Extraction and purification of $D N A$. Washed cell pellets were lysed in a solution containing $100 \mathrm{~mm}-\mathrm{Tris} / \mathrm{HCl}$, pH 8.0, $50 \mathrm{~mm}$-EDTA and $2 \%(\mathrm{w} / \mathrm{v})$ Sarkosyl. The cells were homogenized for $5 \mathrm{~min}$ at $4{ }^{\circ} \mathrm{C}$ in a Dounce homogenizer and then $1 \mathrm{~g}$ solid $\mathrm{CsCl}(\mathrm{BRL})$ and $0.1 \mathrm{ml}$ ethidium bromide $\left(10 \mathrm{mg} \mathrm{ml}^{-1}\right)$ were added per $\mathrm{ml}$ of lysate. The solution was added to nitrocellulose tubes and centrifuged to equilibrium in an $\mathrm{SW} 50.1$ rotor (Beckman) at $250000 \mathrm{~g}$ for $48 \mathrm{~h}$ at $20^{\circ} \mathrm{C}$. The band of DNA was visualized by UV light, and recovered by puncturing the side of the tube with an 18 -gauge needle and collecting in a $1 \mathrm{ml}$ syringe. The ethidium bromide was removed by extracting twice with an equal volume of $5 \mathrm{M}-\mathrm{NaCl}, 0 \cdot 1 \mathrm{M}-\mathrm{Tris} / \mathrm{HCl}, \mathrm{pH} 8 \cdot 6$, and 5 mm-EDTA saturated with propan-2-ol. The aqueous phase was diluted with 2 vols distilled water and precipitated by addition of 2 vols ethanol. The precipitated DNA was spooled on a glass rod, resuspended in TE buffer $(0 \cdot 01 \mathrm{M}-\mathrm{Tris} / \mathrm{HCl}$, pH 8.0, 1 mM-EDTA), and treated with $100 \mu \mathrm{g} \mathrm{RNAase} \mathrm{A} \mathrm{ml}{ }^{-1}$ for $30 \mathrm{~min}$ at $37^{\circ} \mathrm{C}$. The RNAase A was removed by extracting twice with an equal volume of TE-saturated phenol and twice with chloroform/isoamyl alcohol $(24: 1, v / v)$. The aqueous phase containing the DNA was removed, precipitated with 2 vols ethanol, spooled on a glass rod and dissolved in TE buffer. DNA to be used for liquid hybridization was further processed as previously described (Stephens et al., 1981).

DNA probe synthesis. Purified DNA was radioactively labelled in ritro using the four labelled nucleoside triphosphates by the nick translation technique previously described (Aulakh \& Gallo, 1977; Aulakh et al., 1979, 1983; Kelly et al., 1970; Maniatis et al., 1975). In brief, the reaction mixture in a final volume of $50 \mu 1$ contained $1 \mu \mathrm{g}$ purified DNA, $50 \mathrm{~mm}$-Tris/ $\mathrm{HCl}, \mathrm{pH} 7 \cdot 5,10 \mathrm{~mm}-\mathrm{MgCl}_{2}, 1 \mathrm{mM}-2$-mercaptoethanol, 6 units DNA polymerase 1 (New England Nuclear), $1 \mu \mathrm{l}$ DNAase I $\left(10^{-7} \mu \mathrm{g} \mathrm{ml}^{-1}\right)$ (Worthington Biochemicals), $27 \mu \mathrm{M}$ of each of the four labelled nucleoside triphosphates (New England Nuclear), and $50 \mu \mathrm{g}$ bovine serum albumin (Cohn fraction $\mathrm{V}$ ) $\mathrm{ml}^{-1}$. The reactions were stopped with $5 \mu \mathrm{l} 5 \%(\mathrm{w} / \mathrm{v})$ SDS and $5 \mu 10 \cdot 1 \mathrm{M}$-EDTA when the specific activity reached approximately $2.0 \times 10^{7}$ c.p.m. per $\mu$ g of DNA. The probes for hybridization reactions were further processed as described by Stephens et al. (1981).

Nucleic acid hybridization reactions. Hybridization reaction mixtures contained $1 \mathrm{mg}$ sheared unlabelled DNA $\mathrm{ml}^{-1}, 0 \cdot 2 \% \mathrm{SDS}, 1 \mathrm{~mm}$-EDTA, $0.48 \mathrm{M}$-phosphate buffer (PB), and 15000 c.p.m. of the sheared $\left[{ }^{3} \mathrm{H}\right] \mathrm{DNA}$ probe in a $100 \mu \mathrm{l}$ reaction volume (Aulakh et al., 1979; Stephens et al., 1981). The reaction mixture was heated to $100^{\circ} \mathrm{C}$ for $5 \mathrm{~min}$ and then incubated at $65^{\circ} \mathrm{C}$ to a $C_{0} t$ value $>300$ (Laird et al., 1969; Aulakh et al., 1979). Hybrid DNA was separated from single stranded DNA on hydroxyapatite columns equilibrated at $60{ }^{\circ} \mathrm{C}$ in $0 \cdot 12 \mathrm{M}-\mathrm{PB}$ and $0 \cdot 2 \%$ SDS. Radioactive material not binding to the columns in $0.12 \mathrm{M}-\mathrm{PB}$ was considered to be single stranded DNA. The double stranded DNA was then eluted with $0.48 \mathrm{M}-\mathrm{PB}$ and $0.2 \%$ SDS. Radioactivity was measured by adding $12 \mathrm{ml}$ Aquasol (New England Nuclear) to $4 \mathrm{ml}$ sample and counting in a Beckman LS scintillation counter. Thermal elution midpoints were determined on hydroxyapatite columns, prepared as described above, by washing with $0.2 \%$ SDS in $0.12 \mathrm{M}$-PB in increments up to $100^{\circ} \mathrm{C}$. Radioactivity was counted as described above.

\section{RESULTS}

$\left[{ }^{3} H\right] D N A-D N A$ hybridization studies. The DNA-DNA hybridization data for the twelve anaerobic strains are listed in Table 2 . Each of the five $\left[{ }^{3} \mathrm{H}\right] \mathrm{DNA}$ probes hybridized extensively with its homologous DNA $(80 \%)$, but not with DNA from duck tissues $(2 \%)$ or from Mycoplasma hominis (3\%) which served as negative controls. 
Table 1. Differential characteristics of anaerobic mycoplasma strains

Data from Robinson \& Allison (1975); Robinson et al. (1975).

$\begin{array}{lcccc}\text { Species and strain } & \text { Serovar } & \begin{array}{c}\text { Bacteriolytic } \\ \text { activity }\end{array} & \begin{array}{c}\text { Requirement } \\ \text { for } \\ \text { cholesterol }\end{array} & \begin{array}{c}\text { Mol \% } \\ \text { G + C }\end{array} \\ \begin{array}{l}\text { A. bactoclasticum } \\ \text { JR }\end{array} & 1 & + & + & \\ 71-B 1 & 1 & + & + & 33 \cdot 7 \\ \text { A-2 } & 1 & + & + & \text { ND } \\ \text { 10A } & 1 & + & + & \text { ND } \\ \text { 5LA } & 2 & + & + & \text { ND } \\ \text { 5LB } & 2 & + & + & \text { ND } \\ 7 \text { LA } & 2 & + & + & 32 \cdot 5 \\ \text { A. ahactoclasticum } & & - & + & 29 \cdot 3 \\ \text { 6-1 } & 3 & - & - & 29 \cdot 5 \\ \text { 171 } & 3 & - & - & 40 \cdot 2 \\ \text { Unclassified } & & - & - & 40 \cdot 3 \\ \text { 161 } & 4 & - & & \text { ND } \\ 162 & 4 & & & \end{array}$

Table 2. Percentage DNA homology using $\left[{ }^{3} \mathrm{H}\right] \mathrm{DNA}$ probes from selected strains of anaerobic mycoplasmas with DNAs from strains of classified and unclassified Anaeroplasma species

Source of uniabelled DNA

$\begin{array}{lr}\text { Species and strain } & \text { Serovar } \\ \begin{array}{l}\text { A. bactoclasticum } \\ \text { JR }\end{array} \\ 71-\mathrm{B} 1 & 1 \\ \text { 10A } & 1 \\ \text { A-2 } & 1 \\ \text { 5LA } & 1 \\ \text { 7LA } & 2 \\ \text { 5LB } & 2 \\ \text { A. abactoclasticum } & 2 \\ \text { 6-1 } & \\ \text { 171 } & 3 \\ \text { Unclassified } & 3 \\ \text { 161 } & \\ \text { 162 } & 4 \\ \text { 163 } & 4 \\ \text { M. hominis } & 4 \\ \text { PG21 } & \\ \text { D } & \end{array}$

Percentage DNA homology of $\left[{ }^{3} \mathrm{H}\right]$ DNA probes*

\begin{tabular}{|c|c|c|c|c|}
\hline JR & A-2 & 5LA & $6-1$ & 161 \\
\hline $100(80)[81]$ & 18 & 2 & 2 & 2 \\
\hline 60 & 12 & 5 & 1 & 2 \\
\hline 19 & $77[80 \cdot 0]$ & 6 & 1 & 5 \\
\hline 16 & $100(81)[81 \cdot 5]$ & 9 & 2 & 1 \\
\hline 13 & 10 & $100(92)[83.0]$ & 2 & 8 \\
\hline 4 & 7 & $74[82 \cdot 0]$ & 2 & 2 \\
\hline 4 & 5 & $85[82.0]$ & 1 & 6 \\
\hline 1 & 3 & 1 & $100(86) \cdot[82 \cdot 4]$ & 3 \\
\hline 3 & 4 & 2 & $92[82 \cdot 0]$ & 2 \\
\hline 1 & 1 & 2 & 1 & $100(93)[82.9]$ \\
\hline i & 3 & 2 & 1 & $86[81]$ \\
\hline 1 & 1 & 1 & $i$ & $94[82 \cdot 5]$ \\
\hline 2 & 1 & 1 & 1 & 2 \\
\hline 1 & 1 & 1 & 1 & 1 \\
\hline
\end{tabular}

* Values in parentheses represent the actual hybridization percentage; values in square brackets represent the thermal elution midpoint of DNA DNA duplexes.

The $\left[{ }^{3} \mathrm{H}\right] \mathrm{DNA}$ probe derived from $A$. bactoclasticum serovar 1 strain JR had $80 \%$ homology to itself, and appreciable homology to $A$. bactoclasticum serovar 1 strain $71-\mathrm{Bl}(60 \%)$, but a very low homology to the other two serovar 1 strains, $10 \mathrm{~A}(19 \%)$ and A-2 $(16 \%)$. There was also $13 \%$ homology to $A$. bactoclasticum serovar 2 strain $5 \mathrm{LA}$ and $4 \%$ or less to all the other anaerobic strains tested. The probe to A. bactoclasticum serovar 1 strain A-2 had $81 \%$ homology to itself, a high degree of homology to serovar 1 strain $10 \mathrm{~A}$ but very low homology to the other two serovar 1 strains JR and 71-B1. These findings indicate that serovar 1 contains two distinct species represented by strains $J R$ and A-2. The probe to serovar 2 strain 5LA showed high homology $(74 \%$ and $85 \%)$ to the two other serovar 2 strains, 5LB and $7 \mathrm{LA}$, but not to the other anaerobic mycoplasma serovars 1,3 and 4 strains, indicating that serovar 2 represents a distinct species. 
The two A. abactoclasticum serovar 3 strains, 6-1 and 171, had a high degree of homology $(92 \%)$ to each other, but very little homology (1-2\%) to the other anaerobic serovar 1,2 and 4 strains tested, and represent a fourth distinct species. The three unclassified serovar 4 strains, 161, 162 and 163 , showed a high degree of homology $(86 \%$ and $94 \%)$ among each other, but $8 \%$ or less to the other serovar 1, 2 and 3 strains tested and represent the fifth distinct species. Thus, based on DNA homology, the anaerobic mycoplasmas fall into five distinct species groups.

$t_{50}$ values of DNA-DNA duplexes. Thermal elution midpoints $\left(\mathrm{te}_{50}\right)$ were determined for each duplex and for a few selected heteroduplexes among members of the same serovar. $A$. bactoclasticum strain JR homoduplex had the lowest te $5_{50}$ value measured $\left(81^{\circ} \mathrm{C}\right)$, whereas unclassified strain 161 and $A$. bactoclasticum strain 5LA had the higher values of 82.9 and $83.0{ }^{\circ} \mathrm{C}$ (Table 2). The te ${ }_{50}$ values of heteroduplexes between members of the same serovar were generally less than $1{ }^{\circ} \mathrm{C}$ below those of the homoduplex, indicating less than $1.5 \%$ mismatching of base pairs in the duplexes (Table 2). The te ${ }_{50}$ values support the close relationship of strains within the five species groups.

Nucleic acid homology of the unclassified anaerobic strains to acholeplasmas. Because both the unclassified anaerobic mycoplasmas and the Acholeplasma species do not require cholesterol for growth, studies were done to determine their genomic relatedness. There was no significant hybridization $(5 \%)$ between a $\left[{ }^{3} \mathrm{H}\right] \mathrm{DNA}$ probe prepared from the unclassified serovar 4 strain 161 and unlabelled DNA from each of the nine established Acholeplasma species (A. laidlawii, PG-9; A axanthum, S743; A. modicum, PG-49; A. equifetale, Cl12; A. oculi, 19L; A. hippikon, Cl; A. granularum, BTS-39; A. morum, S2; A. florum, L1), and from three unclassified Acholeplasma strains (PS2, J233 and 0502). Thus, the unclassified nonsterol-requiring anaeroplasmas have no genomic relatedness to the established nonsterol-requiring acholeplasmas.

\section{DISCUSSION}

The results presented indicate that there are five distinct and separate groups of anaerobic mycoplasmas based on DNA homology studies. Each group warrants species designation based on both phenotypic and genotypic properties. There are four sterol-requiring and one nonsterolrequiring species. There are two distinct species in the serovar 1 Anaeroplasma bactoclasticum group, the serovar 2 group represents a third Anaeroplasma species and the A. abactoclasticum serovar 3 group represents a fourth. We propose that the serovar 1 group be separated into two distinct species based on the DNA homology data.

The four sterol-requiring Anaeroplasma species can readily be separated from the unclassified nonsterol-requiring anaerobic mycoplasmas on the basis of the mol $\% \mathrm{G}+\mathrm{C}$, which for the Anaeroplasma species ranges from $29 \%$ to $34 \%$ whereas in the unclassified anaerobic mycoplasma serovar 4 group it is $40 \%$. Because of their distinctly separate genomic properties, we propose that the nonsterol-requiring anaerobic mycoplasmas be placed in a separate genus from the Anaeroplasma species.

The unclassified anaerobic mycoplasma serovar 4 group and the Acholeplasma species are both nonsterol-requiring mycoplasmas, but they are readily distinguished by their phenotypic and genotypic properties. The Acholeplasma species grow under aerobic conditions and the anaeroplasmas do not. The mol $\% \mathrm{G}+\mathrm{C}$ of the DNA is only $29-33 \%$ for the Acholeplasma species and $40 \%$ for the unclassified anaerobic serovar 4 mycoplasmas. Moreover, the acholeplasmas are distinct from the unclassified anaerobic serovar 4 group based on the DNA homology presented in this report. The question which remains unanswered is whether the unclassified nonsterol-requiring anaerobic mycoplasmas should be placed in the family Acholeplasmataceae because they are nonsterol-requiring or remain with the anaerobic mycoplasma group. We propose that the unclassified nonsterol-requiring anaerobic mycoplasmas be given genus designation and remain in the anaerobic mycoplasmas which would then consist of the genus Anaeroplasma containing four species, and a second genus for the unclassified serovar 4 group containing one species. For these reasons, we believe that the anaerobic mycoplasmas merit family designation within the class Mollicutes. 
The results presented indicate that immunological and other phenotypic properties are not always adequate for speciation of the anaerobic mycoplasmas, as evidenced by the fact that the antigenically distinct serovar 1 group of $A$. bactoclasticum contains two distinct species based on DNA homology studies.

\section{REFERENCES}

Aulakh, G. S. \& Gallo, R. C. (1977). Rauscherleukemia-virus related sequences in human DNA. Presence in some tissues of some patients with hemotopoietic neoplasias and absence in DNA from other tissues. Proceedings of the National Academy of Sciences of the United States of America 74, 353-357.

Aulakh, G. S., Tully, J. C. \& Barile, M. F. (1979). Differentiation among some acholeplasmas by nucleic acid hybridization. Current Microbiology 2, 9194.

Aulakh, G. S., Stephens, E. B., Rose, D. L., Tully, J. G. \& Barile, M. F. (1983). Nucleic acid relationships among Acholeplasma species. Journal of Bacteriology 153, 1338-1341.

Bove, J. M., Saillard, C., Junca, P., DegorceDumas, J. R., Ricard, B., Nhami, A., Whitcomb, R. F., Williamson, D. \& Tully, J. C. (1982). Guanine plus cytosine content, hybridization percentages, and EcoRI restriction enzyme patterns of spiroplasmal DNA. Reviews of Infectious Diseases 4, SI29-SI36.

Chandler, D. K. F., Razin, S., Stephens, E. B., Harasawa, R. \& Barile, M. F. (1982). Genomic and phenotypic analyses of Mycoplasma pneumoniae. Infection and Immunity 38, 604-609.

Christiansen, C. E., Black, F. T. \& Freundt, E. A. (1981). Hybridization experiments with deoxyribonucleic acid from Ureaplasma urealyticum serovars I to VIII. International Journal of Systematic Bacteriology 31, 259-262.

Kelly, R. B., Cozzarelli, N. R., Deutscher, M. P., LeHMAN, I. R. \& KorNBERG, A. (1970). Enzymatic synthesis of deoxyribonucleic acid. Journal of Biological Chemistry 245, 39-45.

Laird, C. D., McConaughy, B. L. \& McCarthy, B. J. (1969). Rate of fixation of nucleotide substitution in evolution. Nature, London 224, 149-154.

Maniatis, T., Jeffery, A. \& Kleid, G. D. (1975). Nucleotide sequence of the rightward operator of phage. Proceedings of the National Academy of Sciences of the United States of America 72, 11841188.

Robinson, I. M. (1979). Special features of the anaeroplasmas. In The Mycoplasmas, vol, 1, Cell
Biology, pp. 515-528. Edited by M. F. Barile \& S. Razin. New York: Academic Press.

Robinson, I. M. (1984). Genus Anaeroplasma, In Bergey's Manual of Systematic Bacteriology, vol. I, pp. 787-790. Edited by N. R. Krieg \& J. G. Holt. Baltimore: Williams and Wilkins.

Robinson, I. M. \& Allison, M. J. (1975). Transfer of Acholeplasma bactoclasticum Robinson and Hungate to the genus Anaeroplasma (Anaeroplasma bactoclasticum Robinson and Hungate comb. nov.): emended description of the species. International Journal of Systematic Bacteriology 25, 182-186.

Robinson, I. M. \& Hungate, R. E. (1973). Acholeplasma bactoclasticum sp. nov.: an anaerobic mycoplasma from the bovine rumen. International Journal of Systematic Bacteriology 23, 171-181.

Robinson, I. M. \& RHOAdes, K. R. (1977). Serological relationships between strains of anaerobic mycoplasmas. International Journal of Systematic Bacteriology 27, 200-203.

Robinson, I. M. \& Rhoades, K. R. (1982). Serologic relationships between strains of anaerobic mycoplasmas. Review of Infectious Diseases 4, S271.

Robinson, I. M., Allison, M. J. \& Hartman, P. A. (1975). Anaeroplasma abactoclasticum gen. nov., sp. nov.: an obligately anaerobic mycoplasma from the rumen. International Journal of Systematic Bacteriology 25, 173-181.

Stephens, E. B., Aulakh, G. S., McCoy, R. E., Rose, D. L., Tully, J. G. \& Barile, M. F. (1981). Lack of genetic relatedness among animal and plant acholeplasmas by nucleic acid hybridization. Current Microbiology 5, 367-370.

Stephens, E. B., Aulakh, G. S., Rose, D. L., Tully, J. G. \& BARILE, M. F. (1983). Intraspecies genetic relatedness among strains of Acholeplasma laidlawii and Acholeplasma axanthum by nucleic acid hybridization. Journal of General Microbiology 129, 19291934.

Tully, J. G. (1979). Special features of the acholeplasmas. In The Mycoplasmas, vol. 1, Cell Biology, pp. 431-449. Edited by M. F. Barile \& S. Razin. New York: Academic Press. 